\title{
МОДЕЛЬ ОРГАНІЗАЦІЙНОГО МЕХАНІЗМУ РОЗПОДІЛУ РЕСУРСІВ ВАГОНОРЕМОНТНИХ ПІДПРИЕМСТВ
}

\author{
MODELS OF ORGANIZATIONAL MECHANISM FOR THE \\ DISTRIBUTION OF RESOURCES WAGON ENTERPRISES
}

\author{
Представив д-р техн. наук, професор А.П. Фалендиш
}

\begin{abstract}
Вагонні депо 3 відповідними ремонтно-заготівельними цехами, що належать до структурних підрозділів вагонного господарства залізниць, призначені для деповського планового й поточного відцепного ремонту вагонів, виготовлення й ремонту запасних частин для пунктів технічного обслуговування й безвідчіпного ремонту вагонів у межах ділянок, прикріплених до депо.
\end{abstract}

Основною умовою забезпечення справного стану вагонного парку в експлуатації $\epsilon$ високоякісне виконання ремонту вагонів у депо. Однак постійно зростаюча інтенсивність експлуатації вагонів вимагає посилення контролю технічного стану і якості ремонту вагонів у пунктах технічного обслуговування й пунктах підготовки їх до перевезень, причому несправності у вагонах повинні бути виявлені й усунуті за час стоянки поїзда, передбачений графіком руху.

Велика увага приділяється теоретичним основам забезпечення працездатності вагонного парку й раціональної організації роботи вагонних депо й механізованих пунктів підготовки вагонів до перевезень, а також питанням наукової організації праці, механізації й автоматизації виробничих процесів.

Серед задач, що розв'язуються в рамках автоматизованої системи управління вагонним господарством, актуальною $\epsilon$ задача раціонального розподілу ресурсів ремонтно-заготівельних цехів, яку доцільно розв'язати за допомогою відповідної моделі.

Постановка задачі розподілу ресурсів. При формалізації постановки задачі побудови моделі істотними $є$ дві обставини. 3 одного боку, система існує для досягнення яких-небудь певних цілей, тобто можна говорити про інтереси системи в цілому. 3 іншого боку, елементи системи найчастіше переслідують власні інтереси, що не збігаються 3 інтересами системи в цілому. Все це дає підставу формалізувати деякі аспекти ii функціонування в термінах теорії ігор.

Будемо розглядати найпростішу дворівневу модельну систему, що складається із Центру й деякої кількості однотипних Елементів. Керування такою системою ми розглянемо на прикладі задачі розподілу ресурсів. Суть цієї задачі полягає в наступному. Елементи (надалі ми будемо називати їх Споживачами) подають Центру заявки на одержання деякого ресурсу (для простоти розглядається один вид ресурсу). Центр на підставі цих заявок розподіляє наявний у його розпорядженні ресурс (який передбачається подільним).

Якщо всі заявки можуть бути повністю задоволені, то Центру, очевидно, так і варто зробити - виділити кожному Споживачеві стільки, скільки він просить. 
Істотно складніше ситуація дефіциту, коли сумарний обсяг заявок перевершує наявний у розпорядженні Центра ресурс. У цьому випадку задача розподілу ресурсу стає нетривіальною. Універсальних рекомендацій тут не існує. Нижче будуть розглянуті деякі способи, або механізми, розподілу ресурсів, кожний $з$ яким має певні переваги й недоліки.

Проведемо формалізацію вищеописаного задачі, описаної вище. $€ n$ Споживачів, кожний 3 яких повідомляє Центру число $s_{i}(i=1,2, \ldots, n)$ - заявку (рисунок), а також, імовірно, ще і деяку інформацію (на рис. позначено пунктирною стрілкою). Далі Центр на підставі заявок Споживачів, наявного в його розпорядженні ресурсу $R$ і додаткової інформації про Споживачів обчислює за деяким правилом числа $x_{i}(i=1,2, \ldots, n)-$ обсяг ресурсу, виділюваний $i$-му Споживачеві.

$$
\text { У випадку } \sum_{i=1}^{n} s_{i} \leq R \quad \text { (відсутність }
$$
дефіциту) природним рішенням Центру $є$ таке: $x_{1}=s_{1}, x_{2}=s_{2}, \ldots, x_{n}=s_{n}$ (кожний Споживач одержує стільки, скільки просив).

Надалі ми будемо вважати виконаною нерівність: $\sum_{i=1}^{n} s_{i}>R \quad$ (сумарна заявка Споживачів перевершує ресурс Центру).

Відзначимо таку важливу обставину. Споживачі формують свої заявки на підставі власних реальних потреб $r_{i}$, які їм відомі, але невідомі Центру. Можна сказати, що числа $s_{i} \epsilon$ стратегіями Споживачів як учасників ієрархічної гри. У свою чергу стратегією Центру є числа $x_{i}$.

Механізм прямих пріоритетів. Механізм прямих пріоритетів належить до числа так званих пріоритетних механізмів, відмітною рисою яких $є$ приписування кожному Споживачеві деякого пріоритету. Поряд з розмірами заявок $s_{i}(i=1,2, \ldots, n)$ Центр ураховує пріоритет кожного
Споживача, що визначається числом $A_{i}$, $(i=1,2, \ldots, n)$.

Відповідно до механізму прямих пріоритетів розподіл ресурсу здійснюється за правилом

$$
x_{i}=\min \left\{s_{i}, \gamma A_{i} s_{i}\right\},(i=1,2, \ldots, n),
$$

де $\gamma$ - загальний для всіх Споживачів параметр, визначається з умови

$$
\sum_{i=1}^{n} x_{i}=R
$$

(весь ресурс розподіляється без залишку).

Особливо простого вигляду формула (1) набуває у випадку "рівності" Споживачів з погляду Центру, тобто при $A_{1}=A_{2}=\ldots=A_{n}=1$ (ця умова не обмежує спільності, але спрощує подальші викладки). Тоді $x_{i}=\min \left\{s_{i}, \gamma s_{i}\right\},(i=1,2, \ldots, n)$ (випадок $x_{i}=s_{i}$ неможливий, тому що при цьому кожний Споживач одержує стільки, скільки просив, а це суперечить припущенню про наявність дефіциту).

$$
3 \text { умови (2) одержуємо } \sum_{i=1}^{n} \gamma s_{i}=R \text {, }
$$

звідки $\gamma=\frac{R}{\sum_{i=1}^{n} s_{i}}$.

Описаний механізм розподілу ресурсів $\epsilon$, мабуть, найпростішим. Зміст його полягає в тому, що всі заявки пропорційно "урізаються" шляхом множення на число $\gamma$.

Переваги механізму прямих пріоритетів очевидні. Відзначимо два недоліки. По-перше, кожний Споживач одержує менше, ніж просить. Тим часом неважко уявити собі ситуацію, коли Споживачеві потрібно на здійснення якогонебудь проекту саме $s_{i}$ одиниць ресурсу, а $\gamma_{i} s_{\mathrm{i}}$ уже не вистачає. По-друге, даний механізм "штовхає" Споживачів до завищення заявок в умовах дефіциту. 
Дійсно, оскільки чим більше Споживач просить, тим більше одержує, він може, завищуючи свої потреби, спробувати наблизити підсумкове рішення Центру $x_{i}$ до своїх реальних потреб $r_{i}$. Тим самим дефіцит ще більше зростає, причому Центр навіть не має можливості довідатися про реальні запити Споживачів $r_{i}$, оскільки вони повідомляють заявки $s_{i}>r_{i}$.

Механізм зворотних пріоритетів. Механізм зворотних пріоритетів грунтується на припущенні, що чим менше потрібно Споживачеві ресурсу, тим більше ефективність його використання. Відповідно до цього розподіл ресурсу здійснюється за правилом

$$
x_{i}=\min \left\{s_{i}, \gamma A_{i} / s_{i}\right\},(i=1,2, \ldots, n),
$$

де число $\gamma$ визначається, як і в механізмі прямих пріоритетів, з умови (2). 3 формули
(3) видно, що, подаючи дуже малу або дуже велика заявку $s_{i}$, Споживач одержує малий pecypc $x_{i}$. Знайдемо, яку ж заявку $s_{i}$ повинен подавати $i$-й Споживач, щоб одержати максимальний ресурс $x_{i}$ (в умовах дефіциту така мета Споживача $є$ цілком зрозумілою). На рисунку зображено графік функції $x_{i}=x_{i}\left(s_{i}\right)$. Видно, що максимум досягається в точці $s_{i}^{*}$, що $€$ розв'язком рівняння $s_{i}^{*}=\gamma \frac{A_{i}}{s_{i}^{*}}$. Перетворюючи останню рівність, одержуємо $s *=\gamma \mathrm{A}$ i $s_{i}^{*}=\sqrt{\gamma A_{i}}$ Таким чином, рівноважним $\epsilon$ набір стратегій Споживачів $s_{1}^{*}=\sqrt{\gamma A_{1}}, s_{2}^{*}=\sqrt{\gamma A_{2}}, \ldots, s_{n}^{*}=\sqrt{\gamma A_{n}}$, при цьому $x_{1}=s_{1}^{*}, x_{2}=s_{2} *, \ldots, x_{n}=s_{n} *$.

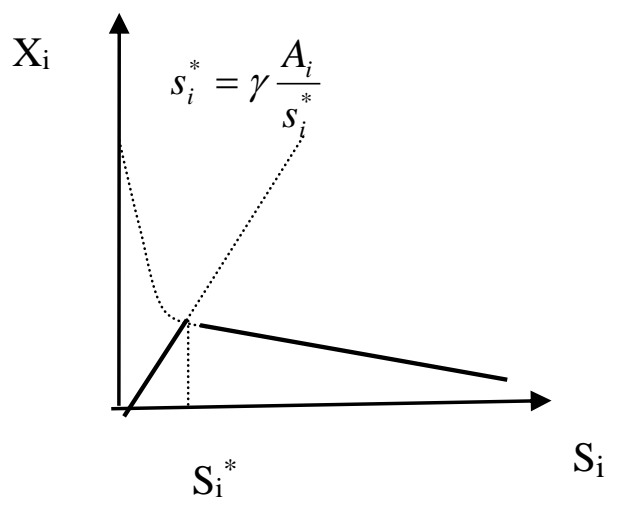

Рис. График функции $\mathrm{x}_{\mathrm{i}}=\mathrm{x}_{\mathrm{i}}\left(\mathrm{s}_{\mathrm{i}}\right)$

Вибираючи замість $s_{i}$ * будь-яку іншу стратегію $s$, $i$-й Споживач лише зменшує виділюваний йому ресурс $x_{i}$.

Залишилося обчислити константу $\gamma$. Маємо

$$
R=\sum_{i=1}^{n} x_{i}=\sum_{i=1}^{n} s_{i}=\sum_{i=1}^{n} \sqrt{\gamma A_{i}}=\sqrt{\gamma} \sum_{i=1}^{n} \sqrt{A_{i}},
$$

звідки

$$
\sqrt{\gamma}=\frac{R}{\sum_{i=1}^{n} \sqrt{A_{i}}}
$$

Зауваження 1. Ще раз відзначимо, що набір стратегій $s_{i}^{*}(i=1,2, \ldots, n) \epsilon$ рівноважним, тобто, подаючи будь-яку заявку $s_{i} \neq s_{i}{ }^{*}, i$-й Споживач лише зменшує виділюваний йому ресурс $x_{i}$. Можна довести, що кожна зі стратегій $s_{i}{ }^{*} \epsilon$ також 
гарантуючої, тобто у випадку застосування $i$-м Споживачем цієї стратегії він у кожному разі (тобто при будь-яких заявках інших Споживачів) одержує не менше, ніж $x_{i}=s_{i}{ }^{*}$.

Зауваження 2. Насправді, ми розглянули випадок, коли $s_{i}^{*}<r_{i}$, для всіх $r_{i}$, тобто коли кожний зі Споживачів змушений, подаючи заявку, занижувати свою реальну потребу. Може бути й так, що для деяких Споживачів $s_{i}^{*} \geq r_{i}$. Тоді ці Споживачі подають заявку на ресурс $s_{i}{ }^{*}=r_{i}$ і стільки ж одержують.

Механізм зворотних пріоритетів має ряд переваг. А саме не відбувається невиправданого завищення заявок, тобто не виникає ситуації

$s_{i}^{*}>r_{i}$. Крім того, за умови розумного поводження Споживачі (тобто при використанні кожним 3 них рівноважної стратегї $s_{i}^{*}$ ) вони одержують стільки, скільки просять. Недоліком $є$ те, що числа $s_{i}{ }^{*}$ швидше за все виявляються менше реальних потреб $r_{i}$. Внаслідок цього Центр не одержує достовірної інформації про реальний дефіцит $\left(\sum_{i=1}^{n} r_{i}\right)-R$.

Конкурсний механізм. Конкурсний механізм застосовується в тих випадках, коли недоцільно "урізати" заявки, оскільки Споживачам ресурс потрібний на реалізацію яких-небудь конкретних проектів, на які меншого ресурсу не вистачить. У цих умовах Центр проводить конкурс заявок. Ті, хто перемагають у конкурсі, повністю одержують необхідний pecypc, a ті, що програли, не одержують нічого. Реалізація цього відбувається в такий спосіб. Споживачі повідомляють Центру свої заявки $s_{i}$, а також величини $w_{i}$, що характеризують ефект, що вони мають намір одержати. На підставі цих даних Центр обчислює для кожного Споживача показник ефективності

$$
e_{i}=\frac{w_{i}}{s_{i}}, i=1,2, \ldots, n
$$

Після цього ресурс розподіляється в такий спосіб. Спочатку розглядається Споживач із найбільшою ефективністю. Йому виділяється стільки, скільки він просить (якщо в Центру вистачає ресурсу). Потім береться другий за ефективністю й т. Д. У якийсь момент виявляється, що на задоволення чергової заявки ресурсу, що залишився, в Центру не вистачає. Тоді цей Споживач так само, як i всі, що залишилися, нічого не одержує.

Зауваження 3. В ефективності описаного механізму можуть виникнути сумніви. Адже Споживачі можуть пообіцяти великий ефект, отримати ресурс, а потім не виконати обіцяного. Тому при реальному застосуванні конкурсного механізму необхідна діюча система контролю (можливо, поетапний контроль для проектів із тривалим часом реалізації).

Механізм відкритого керування. У всіх розглянутих вище механізмах розподілу ресурсів Споживачі можуть домогтися кращого для себе рішення Центра шляхом перекручування інформації. Таким чином, Центр не одержує достовірних даних про запити Споживачів.

Можливість ефективно управляти на підставі недостовірно інформації $\epsilon$ сумнівною. Тому цікаві механізми відкритого керування, ідея яких полягає в створенні для Споживачів стимулів до повідомлення в заявці своїх реальних потреб.

Опишемо один 3 можливих механізмів відкритого керування. Розподіл ресурсів проводиться в кілька етапів. На першому етапі ресурс розділяється нарівно між всіма Споживачами, тобто по $R / n$ кожному. Якщо заявки яких-небудь Споживачів виявилися не більше ніж $R / n$, то вони повністю задовольняються. Тим самим кількість Споживачів зменшується до $n_{l}$, зменшується й ресурс Центру - до $R_{l}$. На другому етапі ресурс розділяється нарівно між тими $n_{1}$ Споживачами, що залишилися, і т. д. 
На якомусь етапі виявляється, що, розділивши ресурс нарівно між Споживачами, що залишилися, не вдається задовольнити жодніої заявки. Тоді всі ці Споживачі одержують нарівно.

Описаний механізм $\epsilon$ механізмом відкритого керування. Дійсно, в остаточному підсумку всі Споживачі поділяються на пріоритетних (які одержали стільки, скільки просили) і непріоритетних. Пріоритетні одержують стільки, скільки просять, тому їм не має сенсу спотворювати свої реальні потреби. Непріоритетні ж, як неважко бачити, не можуть збільшити виділений їм ресурс ні підвищуючи, ні знижуючи свою заявку. Таким чином, при розподілі ресурсів відповідно до описаного механізму Центр одержує достовірну інформацію про реальні запити Споживачів.

Відкрите керування й експертне опитування. Якщо потрібно визначити обсяг фінансування великого проекту, то часто удаються до проведення експертного опитування. Розглянемо таку процедуру опитування. Кожному $3 n$ експертів пропонується повідомити число $s$ з відрізка $[d ; D]$, після чого на підставі експертних оцінок визначається підсумковий розв'язок $x$. Задача полягає саме в тім, щоб визначити число $x$ виходячи із заданих $s_{i}(\mathrm{i}=1,2, \ldots, \mathrm{n})$.

На перший погляд здається, що найкраще рішення тут - взяти в якості підсумкового рішення середньоарифметичне думок експертів:

$$
x=\frac{1}{n} \sum_{i=1}^{n} s_{i} .
$$

Однак у такого рішення $\epsilon$ істотний недолік. Справа полягає в наступному. У кожного експерта $\epsilon$ думка $r_{i}$ щодо обсягу фінансування. I якщо експерт яким-небудь чином зацікавлений у тім, щоб підсумкова оцінка $x$ збіглася $з$ його думкою $r_{i}$, то він може намагатися домогтися цього збігу, повідомляючи оцінку $s_{i} \neq r_{i}$.
Зауважсення 4. У теорії колективного прийняття рішень такий спосіб дій називається маніпулюванням. У свою чергу, якщо механізм колективного прийняття рішень допускає маніпулювання із чиєї-небудь сторони, то він називається таким, яким маніпулюють. Спотворюючи свої справжні переваги, можна наблизити підсумкове колективне рішення до власної справжньої переваги.

Повернемося до експертного опитування. Говорячи більш строго, $i$-й експерт розв'язує задачу $\left|x-r_{i}\right| \rightarrow \min _{s_{i}}$, тобто намагається мінімізувати різницю між підсумковим рішенням $x$ i своєю справжньою думкою $r_{i}$ шляхом належного вибору повідомлюваної оцінки $s_{i}$. Опишемо механізм виробітку рішення $x^{*}$, що $\epsilon$ механізмом відкритого керування (тобто механізмом, яким не маніпулюють). Нагадаємо, що експерти повідомляють свої оцінки $\quad s_{i} \in[d, D], i=1,2, \ldots, n . \quad$ Будемо вважати, не обмежуючи загальності, що оцінки експертів розташовані не за спаданням $s_{1} \leq s_{2} \leq \ldots \leq s_{n}$ (цього завжди можна домогтися перенумерацією експертів). Обчислюються $\mathrm{n}$ допоміжних чисел $v_{i}=D-(i-1) \frac{D-d}{n}, i=1,2, \ldots, n \quad$ (ці числа ділять відрізок $[d, D]$ на $n$ рівних частин). Після цього для кожного і береться менше із двох чисел $s_{i}$ і $v_{i}: \min \left\{s_{i}, v_{i}\right\}$. I, нарешті, із всіх цих мінімумів обирається найбільший, котрий i $\epsilon$ підсумковим розв'язком:

$$
x^{*}=\max _{1<i>n} \min \left\{s_{i}, v_{i}\right\} .
$$

Зауважкення 5. У всіх попередніх міркуваннях кваліфікація експертів передбачається однаковою. Можна, якщо буде потреба, вводити коефіцієнти, що дозволяють враховувати думку різних експертів різним чином - принципово це нічого не змінює, лише дещо 
ускладнюється обчислення підсумкового результату $x^{*}$.

На базі описаної моделі був розроблений моделюючий алгоритм та його програмна реалізація в середовищі VB6.0, за допомогою яких проведено дослідження процесу розподілу ресурсів ремонтнозаготівельних цехів при різних умовах постачання та зроблено певні рекомендації щодо стратегії використання різних методик і їх доцільності.

\section{Сиисок літератури}

1. Фон Нейман, Дж. Теория игр и экономическое поведение [Текст] / Дж. фон Нейман, О. Моргенштерн. - М., НАУКА, 1970. - 983 с.

2. Ломкова, Е.Н. Экономико-математические модели управления производством (теоретичемкие аспекты) [Текст]: учеб. пособие / Е.Н. Ломкова, А.А. Эпов. - Волгоград: ВолгГТУ, 2005. - 67 с.

3. Глущенко, В.В. Глущенко И.И. Розработка управленческого решения. Прогнозирование - планирование - оценка. Теория проектирования экспертов [Текст]: учеб. для вузов. - М.: ЮНИТИ-ДАНА, 2000. - 436 с.

\section{Анотаціï}

Стаття присвячена одному з аспектів, спрямованому на забезпечення транспортної мережі залізниць навантажувальними ресурсами. Розглядаються питання визначення найбільш раціонального рівня прийняття рішень, розподілу повноважень і відповідальності при розподілі ресурсів ремонтних баз. Формалізовано модель цього процесу 3 використанням апарата теорії ігор.

Статья посвящена одному из аспектов, направленному на обеспечение транспортной сети дороги погрузочными ресурсами. Рассматриваются вопросы определения наиболее рационального уровня принятия решений, распределения полномочий и ответственности при распределении ресурсов ремонтных баз. Составлена модель этого процесса с использованием аппарата теории игр.

The article is devoted to one aspect of which is aimed at ensuring the transport network of roads and loading resources. The questions of definition of the most rational decision-making level, distribution of powers and responsibilities in the allocation of resources repair bases. Compiled model of this process with the use of game. 